\title{
Use of endodontic paper points and Schirmer strips for measurement of tear flow in red-lored parrots (Amazona autumnalis)
}

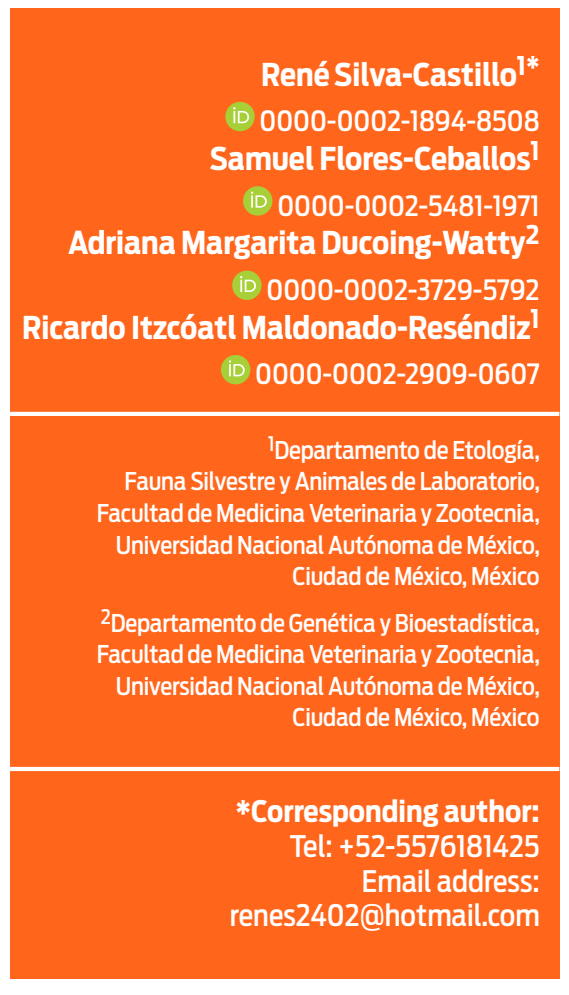

(iD) 0000-0002-1894-8508

Samuel Flores-Ceballos ${ }^{1}$

(iD 0000-0002-3729-5792

iD 0000-0002-2909-0607

'Departamento de Etología, Fauna Silvestre y Animales de Laboratorio, Facultad de Medicina Veterinaria y Zootecnia, Cludatónoma de México,

2Departamento de Genética y Bioestadistica, Facultad de Medicina Veterinaria y Zootecnia, Universidad Nacional Autónoma de México, Ciudad de México, México

Corresponding author:

+52-5576181425

Email address:

renes2402@hotmail.com

Accepted: $\quad 2018-12-13$

Published: 2019-03-22

Additional information and declarations can be found on page 6

@) Copyright 2019 René Silva-Castillo et al.

open access $\boldsymbol{\partial}$

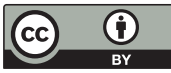

Distributed under Creative Commons CC-BY 4.0

\section{Abstract}

Ocular diseases are sub-diagnosed in bird species, partly because of limited diagnostic methods and lack of reference data. Placement of Schirmer tear test strips in the bottom of the conjunctival sac of birds for tear flow measurement can prove to be difficult, whereas paper tips commonly used for dental procedures may be easier to use, due to a more adequate size and shape. Hence, the aim of this study was to assess and compare tear flow values, using ABC Dental ${ }^{\circledR}$ \# 30 color paper tips and TearFlo ${ }^{\text {TM }}$ Test strips in Red-lored Parrots (Amazona autumnalis) $(\mathrm{n}=26)$. Captive birds of undetermined sex were housed in groups under similar environmental conditions and fed the same diet. All animals were deemed healthy through remote and physical examinations. Average tear flow values of $0.6365 \pm 0.032 \mathrm{~cm} / \mathrm{min}$ and $0.5942 \pm 0.032 \mathrm{~cm} / \mathrm{min}$ were obtained with the Schirmer strips test and the endodontic tips respectively. Lack of difference in observed values between measurement techniques $(p=0.3629)$ indicates that endodontic tips may be a good alternative for tear flow assessment in Red-lored parrots. In addition, endodontic tips are more cost effective and may be less invasive. This study stresses the need to establish species specific ophthalmic reference values for clinical practice in birds, since differences have been reported even in specimens within the same genus.

Keywords: Tear flow, Schirmer strips, Endodontic paper points, Red-lored parrot (Amazona autumnalis)

\section{Cite this as:}

Silva-Castillo RO, Flores-Ceballos S, Ducoing-Watty AM, Maldonado-Reséndiz RI. Use of endodontic paper points and Schirmer strips for measurement of tear flow in Redlored Parrots (Amazona autumnalis). Veterinaria México OA. 2019;6(1). doi: 10.22201/ fmvz.24486760e.2019.1.624 


\section{Introduction}

The red-lored parrot (Amazona autumnalis, order Psittaciformes) measures 32$35.5 \mathrm{~cm}$ in length, weighs between 314 and 485 grams, and has a life span of 20 to 60 years. It has bright green plumage, a red forehead, a blue crown, and yellow cheeks. This species can be found in Brazil, Colombia, Ecuador, Mexico, Panama and Venezuela, and it is currently listed in the Appendix II of CITES. ${ }^{1}$

Ophthalmological examination in birds are similar to those in mammals, and generally follow a complete physical assessment and an extensive clinical history. ${ }^{2}$ However, eye diseases are often sub-diagnosed in bird species, partly due to limited diagnostic methods and lack of reference data. Determination of tear flow should be routinely included test in any eye examination. ${ }^{3}$

Several ocular problems and diseases have been reported in psittacine birds, including peri-orbital lesions, ${ }^{4}$ bilateral supra-orbital abscesses, ${ }^{2}$ corneo-conjunctival dermoid cysts, ${ }^{5}$ blepharo-conjunctivitis due to staphylococci, and fungal keratitis. ${ }^{2}$ Also, exophthalmos secondary to squamous cell carcinoma in the infraorbital sinus has been found in an eclectus parrot (Eclectus roratus solomonensis) ${ }^{6}$ or secondary to retrobulbar adenoma in an African gray parrot (Psittacus erithacus). ${ }^{7} \mathrm{~A}$ periorbital liposarcoma has also been diagnosed for this last species. ${ }^{8}$

The Schirmer tear test strips can be used for tear flow measurement in birds, but reference data is limited for most species that are usually taken for consultation. Also, placement of strips in the bottom of the conjunctival sac of birds can prove to be difficult. Tear flow reference values for Red-lored parrots (Amazona autumnalis) are nonexistent. However, reference data can be found for larger parrots, such as the African gray parrots (Psittacus erithacus, $8 \pm 1.5 \mathrm{~mm} / \mathrm{min}$ ), and for smaller species, such as lories and conures $(4.5 \pm 1 \mathrm{~mm} / \mathrm{min}) .{ }^{9}$ Ophthalmic parameters have also been described in ostriches (Struthio camelus), ${ }^{10}$ anseriformes, ${ }^{11}$ blue macaws (Ara ararauna), ${ }^{12}$ yacos (Psittacus erithacus), eclectic parrots (Eclectus roratus) and parrots of the genus Pionus, ${ }^{13}$ as well as in pigeons (Columba spp.). ${ }^{14}$

Paper tips that are commonly used for endodontic procedures, have a high absorptive capacity and a conical shape that may be better suited for measurement of tear flow in eyes of birds. ${ }^{15}$ They are also cheaper than Schirmer strips and are readily available, hence being a potential alternative to measure tear flow in this and other bird species.

The Red-lored parrot is a commonly kept pet in Mexico, and ophthalmic reference values need to be established for use in routine clinical examinations that involve eye inspection.

\section{Hypothesis}

Endodontic paper points (ABC Dental ${ }^{\circledR}$ \# 30 color paper tips) are as efficient as TearFloTM test strips for measuring tear flow in Red-lored parrots (Amazona autumnalis).

\section{Objectives}

- To establish and compare tear flow values by use of endodontic paper tips and of Schirmer strips in captive red-lored parrots.

- To assess tear flow differences between right and left eyes. 


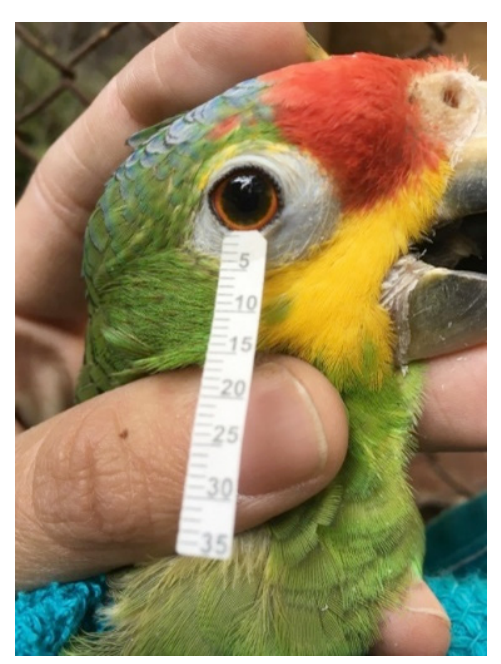

Figure 1. Measurement of tear flow in red-lored parrots using TearFloTM Test Strips.

- To assess tear flow differences before and after sedation of birds with intranasal midazolam.

\section{Material and methods}

For this study 26 captive adult red-lored parrots (Amazona autumnalis) of undetermined sex, were used. Birds were housed in groups at "El Nido" aviary located in Ixtapaluca, State of Mexico. Environmental conditions and diets were similar for all animals. Parrots were deemed healthy by remote and physical examinations, where mental state, heart rate, respiratory rate, temperature, color of the cloacal mucosa, and body condition were determined. All birds with signs of disease or abnormalities in eyes or periocular regions were excluded from the study.

Birds were briefly restrained in two consecutive days to measure tear flow. A physical examination was also performed during the first day, and no sedation was used. During the second day, intranasal midazolam was administered as a sedative agent, and care was taken to measure tear flow only after sedation effects had been confirmed.

\section{TearFloTM test strips}

Tear flow was assessed in each eye by placing a strip in the bottom of the conjunctival sac for 60 seconds. The strip was then removed, and the wet segment immediately measured, using the printed metric scale for test interpretation (Figure 1).

\section{ABC Dental $\mathbb{B}$ \# 30 colored paper tips}

As for the TearFlo strips, endodontic paper tips were placed in the ventral fornix of the inferior eyelid of each eye for 60 seconds, then removed and the wet segment immediately measured using a caliper to determine tear flow (Figure 2). ${ }^{16}$ 


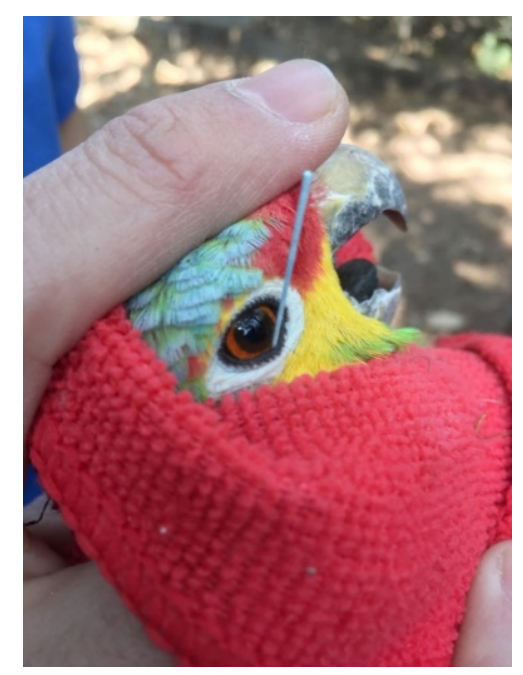

Figure 2. Measurement of tear flow in red-lored parrots using ABC Dental ${ }^{\circledR}$ color paper tips \# 30.

\section{Statistical analysis}

Differences in tear flow were analyzed by ANOVA with JMP statistical software (SAS). The fixed variables were measuring method (Schrimer strips or endodontic tips), eye (left or right), sedation, and their interactions up to the second order. The parrot was considered as a random variable. To calculate the $\mathrm{F}$ statistic for the fixed effects and their first order interactions, the error term was the interaction between said fixed variable(s) and the random variable. For higher order interactions the residual error of the model was used. ${ }^{17}$

\section{Results and discussion}

Tear production seems to be related to the size of eye orbits and tissue of lacrimal glands, hence imposing a challenge and denoting an absence of reference values for a wide range of bird species. ${ }^{2}$ This shortcoming is usually handled in daily practice by using a second (clinically normal) bird of the same species, and preferably the same household, to compare values of interest, that could help detect ophthalmic alterations. ${ }^{2}$ Nonetheless, establishment of reference values for clinical practice is imperative.

Endodontic paper points have not been standardized for measurement of tear flow. However, their use for this purpose has been previously assessed in birds, ${ }^{16}$ marmoset monkeys, ${ }^{14}$ rabbits ${ }^{18}$ and cats. ${ }^{19}$ Differences in brands, sizes and specific characteristics of paper tips, such as trabecular density or type of cellulose fiber should be considered to determine efficiency and to establish appropriate reference values. ${ }^{20}$ Use of paper tips for tear flow measurement was found to be cheaper than Schirmer strips in this study, representing nearly 3\% of the cost.

Placement of both Schirmer strips and paper tips in the bottom of the conjunctival sac proved to be difficult in this study, since the nictitating membranes moved repeatedly, constantly dislodging the strip during measurement of tear flow. This difficulty was also reported by Falcão et al. when making measurements of tear flow with Schirmer strips in macaws. ${ }^{3}$ The correct restraining of a bird is certainly important to accomplish an adequate measurement, since improper handling causes 
Table 1. Average tear flow per eye in Red-lored parrots, using two different measurement methods.

\begin{tabular}{|l|c|c|}
\hline \multicolumn{1}{|c|}{ Measurement method } & $\begin{array}{c}\text { Tear flow } \\
(\mathbf{c m} / \mathbf{m i n})\end{array}$ & Standard Error \\
\hline Tear Flo ${ }^{\mathrm{TM}}$ Test Strips & 0.6365 & 0.0322 \\
\hline ABC Dental ${ }^{\circledR}$ \# 30 Colored paper tips & 0.5942 & 0.0322 \\
\hline
\end{tabular}

Table 2. Average tear flow per eye in red-lored parrots.

\begin{tabular}{|c|c|c|}
\hline Eye & $\begin{array}{c}\text { Tear flow } \\
(\mathbf{c m} / \mathbf{m i n})\end{array}$ & Standard Error \\
\hline Left & 0.6192 & 0.0175 \\
\hline Right & 0.6115 & 0.0175 \\
\hline
\end{tabular}

stress on the bird, which can lead to more difficulty in placing and keeping the strips in the correct position, resulting in a faulty tear flow measurement, that could lead to erroneous results. Lange et al. indicated a further complexity for the use of this technique in marmoset monkeys (Callitrhrix penicillata), since two people were needed (one to restrain the animal and one to place the strip) for adequate tear flow measurement in this species. ${ }^{14}$ However, placement of paper strips in the bottom of the conjunctival sac of marmoset monkeys did not appear to be as hard comparatively, allowing a decreased waste of tips and often accomplishing measurement on the first try.

Results of this study indicate that both TearFlow test strips and ABC dental \#30 paper tips are viable methods for measurement of tear flow in Red-lored parrots. No difference was found in average tear flow between methods ( $p=0.3629$; Table 1). Average tear flow was also found to be similar for both eyes ( $p=0.7597$; Table 2$)$. Observed tear flow values per eye were of 0.6365 $\mathrm{cm} / \mathrm{min}$ using the Tear FloTM Strip test, and of $0.5942 \mathrm{~cm} / \mathrm{min}$ using the ABC Dental ${ }^{\circledR}$ \# 30 colored paper tips (Table 1). Storey et al. found similar results $(7.9 \pm 2.6 \mathrm{~mm} / \mathrm{min})$ when measuring tear flow in Amazona ventralis with the Schirmer test. ${ }^{21}$ However, Monção et al. reported a tear production of $14.9 \pm 1.6 \mathrm{~mm} / \mathrm{min}$ and $13.1 \pm 1.4 \mathrm{~mm} / \mathrm{min}$ in captive Amazona amazona and Amazona aestiva respectively, when using absorbent paper tips. ${ }^{16}$ This difference in tear flow measurements with the results of this study when using the endodontic tip technique could be due to specific characteristics of tips used, as mentioned by Lima et al. ${ }^{20}$ and Pumarola et al. ${ }^{18}$ Also, even if minimal, the degree of corneal and/or conjunctival irritation caused by differences in tips used could have affected tear flow. ${ }^{18,20}$ In addition, observed differences in tear flow could have been influenced by environmental conditions, since eye moisture is reduced when animals are exposed to dry environments (64-76\% humidity levels in the Monção et al. study vs 38-58\% humidity for this study). 19,22

The use of intranasal midazolam to sedate birds can have minimal cardiopulmonary effects. ${ }^{23}$ Also, the low pH of midazolam (3.0-3.5) can induce a burning eye sensation and lacrimation. ${ }^{24}$ Moreover, children can develop nasal congestion, nasopharyngeal irritation and bad taste after intranasal midazolam administration. ${ }^{25}$ This sedative may also induce sneezing in dogs 26 and psittacines (Amazona aestiva and Amazona amazonica) ${ }^{27}$ when administered intranasally. Lacrimation was observed after the administration of midazolam in only one of the 26 assessed birds in this study, and sedation did not affect tear flow values $(p=0.9329)$. Hence, midazolam can be used to facilitate handling of birds and placement of paper strips, without affecting tear flow values, independently of technique used. There were no significant interactions between the studied variables ( $p>0.05$ ) 


\section{Conclusions}

1 This study provides tear flow reference values for clinical use in the Amazona autumanlis species.

- Endodontic tips can potentially be used for tear flow measurement in several species (especially in those having smaller eyes). This technique is also more cost-effective than the Schirmer strip test.

1 This study stresses the need to establish species specific ophthalmic reference values for clinical practice in birds, since differences have been reported even in specimens within the same genus.

\section{Funding}

René Silva Castillo.

\section{Acknowledgements}

The authors wish to thank staff and employees of the "El Nido" Aviary research and conservation center.

\section{Conflicts of interest}

None.

\section{Author contributions}

R.S.C.: project design, experimental work, manuscript preparation; S.F.C.: project design, experimental work, manuscript preparation; A.M.D.W.: statistical analyses; R.I.M.R.: project coordination and manuscript revision.

\section{References}

1. Gómez de Silva $\mathrm{H}$, Ita Oliveras DE, Medellín RA. Amazona autumnalis. Vertebrados superiores exóticos en México, diversidad, distribución y efectos potenciales. México: Instituto de Ecología, Universidad Nacional Autónoma de México; 2005.

2. Bayón A, Almela RM, Talavera J. Avian ophthalmology. Eur J Comp Anim Pract 2007;17:1-13.

3. Falcão MSA, Monteiro RV, Carvalho CM, Hudson HH, Galera PD. Reference values for selected ophthalmic tests of the blue-and-yellow macaw (Ara ararauna) Pesq Vet Bras. 2017;37:389-94.

4. Soto Piñeiro CJ, Bert E. Valoraciones clínicas de los problemas respiratorios en las aves ornamentales. REDVET. 2010;11:1-27.

5. Hvenegaard AP, Safatle AMV, Guimarães MB, Ferreira AJP, Barros PSM. Retrospective study of ocular disorders in Amazon parrots. Pesq Vet Bras. 2009;29:979-84.

6. Eclectus S, Eclectus P, Diaz-figueroadvm AO, Jrdvm TNT, Avian DA, Williamsms J, et al. Squamous cell carcinoma of the infraorbital sinus with fungal tracheitis and ingluvitis in an adult solomon eclectus parrot (Eclectus roratus solomonensis). J Avian Med Surg. 2006;20:113-9.

7. Simova-curd S, Richter M, Ecvo D. Surgical removal of a retrobulbar adenoma in an African grey parrot (Psittacus erithacus). J Avian Med Surg. 2008;23:24-8. 
8. Graham JE. Periorbital liposarcoma in an African grey parrot (Psittacus erithaCUS). J Avian Med Surg. 2009;3:147-53.

9. Branson R, Harrison G, Harrison L. Avian medicine: principles and application. Florida: Wingers Publishing; 1994.

10. Selk M, Sabzevari A, Vahedi $H$, Golezardy $H$. Determination of reference values for intraocular pressure and schirmer tear test in clinically normal ostriches (Struthio camelus). J Zoo Wild Med. 2012;2:229-32.

11. Ansari-Mood M, Mehdi-Rajaei S, Ghazanfari-Hashemi S, Williams D, Sadjadi R. Measurement of tear production and intraocular pressure in ducks and geese. Vet Ophtalmol. 2017: Vol. 20. 53-57.

12. Falcão M, Monteiro R, Oriá A, Galera P. Modified Schirmer tear test and rebound tonometry in blue-fronted Amazon parrot (Amazona aestiva). Pesq Vet Bras. 2017;37:871-3.

13. Holt $E$, Rosenthal $K$, Shofer $F$. The phenol red thread tear test in large Psittaciformes» Vet Ophthalmol. 2006;9:109-13.

14. Hayat A, Biricik HS. Paper Measurement of tear secretion in healthy pigeons by using the phenol red thread test. Veterinary Record. 2014.

15. Lange R, Lima L, Montiani-ferreira F. Measurement of tear production in black-tufted marmosets (Callithrix penicillata) using three different methods : modified Schirmer' $\mathrm{s}$ I, phenol red thread and standardized endodontic absorbent paper points. Vet Ophthalmol. 2012;376-82.

16. Monção-Silva R, Ofri R, Raposo AC, Araújo N, Torezanic J, Muramoto $C$, et al. Ophthalmic diagnostic tests in parrots (Amazona amazônica) and (Amazona aestiva). J Exot Pet Med. 2016;25:186-93. http://dx.doi.org/10.1053/j. jepm.2016.05.002

17. Maxwell S., Delaney H. Designing experiments and analysing data. Belmont, CA: Wadsworth Publishing; 1990. p. 495-551

18. Lima L, Ribas R, Turner A, Montinai F. Evaluation of standardized endodontic paper point tear test in New Zealand white rabbits and comparison between corneal sensitivity followed tear tests. Vet Ophthalmol. 2015;18 Suppl 1:119-24.

19. Pontes A, Ferreira E, Santos A, Lima N, Conceição D. Lacrimal production of cats: Schirmer tear test, phenol red thread tear test and endodontic absrobent paper point. Eniclopédia Biosfera. 2015:2085-2091. 10.18677/ Enciclopedia_Biosfera_2015_182.

20. Pumarola-Sufi J, Sold-Vicens L, Sentis-Vilalta J, Canalda-Sahli C, Brau-Aguadd E. Absorbency properties of different brands of standardized endodontic paper points. J Endodont. 1998;24:1-2.

21. Storey E, Carboni D, Kearney M, Tully T. Use of phenol red thread tests to evaluate tear production in clinically normal Amazon parrots and comparison with Schirmer tear test findings. J Am Vet Med Assoc. 2009;235:1 181-7.

22. Abusharha AA, Pearce El. The effect of low humidity on the human tear film. Cornea. 2012;32:429-34.

23. Mans C, Sanchez D, Lahner L, Murphy J, Sladky K. Sedation and physiologic response to manual restraint after intranasal administration of midazolam in hispaniolan Amazon parrots (Amazona ventralis). J Avian Med Surg. 2012;26:130-9. 
24. Vesal N, Eskandari M. Sedative effects of midazolam and xylazine with or without ketamine and detomidine alone following intranasal administration in ringnecked parakeets. J Am Vet Med Assoc. 2006;228:383-8.

25. Rawat $H$, Saraf $R$, Sunil V. Effects of intranasal midazolam as premedication in paediatric anaesthesia. A clinical study. Ped Anesth Crit Care J. 2014;2:112-21.

26. Charalambous M. Intranasal midazolam versus rectal diazepam for the management of canine status epilepticus: a multicenter randomized parallel-group clinical trial. J Vet Intern Med. 2017;31:1149-58.

27. Schaffer D, Nayone L, Raposo A, Martins E, Vieira J, Oriá A. Sedative effects of intranasal midazolam administration in wild caught bluefronted Amazon ( $\mathrm{Am}$ azona aestiva) and orange-winged Amazon (Amazona amazonica) parrots. J Avian Med Surg. 2017;31:213-8. 